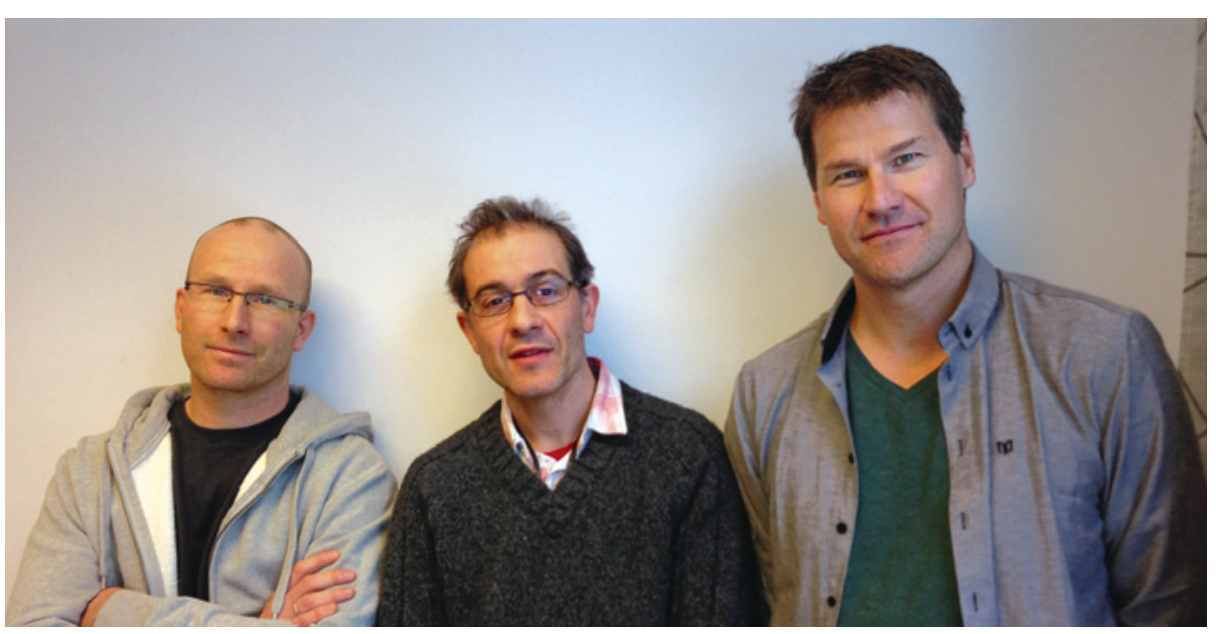

Fra venstre Ottar Bjerkeset, Pål Romundstad og Johan Håkon Bjørngaard. Foto privat

\title{
Mors alder, fødselsrekkefølge og selvmord
}

\author{
Å ha ung mor og å være yngst i søskenflokken gir høyere risiko \\ for selvmord.
}

Flere studier har funnet sammenheng mellom fødselsrekkefølgen i søskenflokk og intelligens, utdanning, inntekt og mortalitet, og nylig er det også vist en sammenheng mellom fødselsrekkefølge og selvmord. Gjennomgående viser studiene mer gunstige utfall for den førstefødte i en søskenflokk. I tillegg viser forskning at barn av unge mødre gjennomgående er mer utsatt for både psykiske problemer, selvmord og lav sosioøkonomisk status. Effektforveksling eller konfundering på grunn av familieforhold, som for eksempel sosioøkonomiske forhold eller genetiske og miljømessige faktorer, kan ha betydning for sammenhengene som er vist mellom fødselsrekkefølge, mors alder og selvmord.

Nå har norske forskere brukt norske registerdata og sammenliknet selvmordsrisiko blant søsken med samme mor, og undersøkte om rekkefølge i søskenflokken og mors alder ved fødsel kan være av betydning (1). Denne tilnærmingen tar høyde for faktorer som deles av medlemmer i en søskenflokk og som kan ha ført til konfundering av resultatene $i$ andre studier. Forskerne benyttet opplysninger fra en kohort på nesten 1,7 millioner nordmenn født i perioden 1967-96, med oppfølging opp til 2008, hvorav 3005 døde som følge av selvmord.

Resultatene viste at selvmordsrisikoen var vesentlig høyere for de yngste sammenliknet med førstefødte i søskenflokken (en økning i suicidrisiko med $46 \%$ for hver plass ut i søskenflokken), mens økende alder på mor hadde en beskyttende effekt (en reduksjon i suicidrisiko på $57 \%$ med en økning på ti år i mors alder).
- Disse resultatene gir en klar indikasjon på at faktorer som ikke er felles mellom søsken i et familiemiljø, og som kan virke allerede $\mathrm{i}$ ung alder, kan ha stor betydning for psykisk helse og selvmordsrisiko mange år senere i livet, sier førsteforfatter Johan Håkon Bjørngaard. - Sammenhengen mellom mors alder og barnas selvmordsrisiko understreker nødvendigheten av forebyggende innsats rettet mot familier med unge mødre og deres barn, sier Bjørngaard.

\section{Forskningsgruppen}

Arbeidet er utført av Johan Håkon Bjørngaard, Lars Vatten, Imre Janszky og Pål Romundstad fra Institutt for samfunnsmedisin og Ottar Bjerkeset fra Institutt for nevromedisin ved Norges teknisk-naturvitenskapelige universitet. Arbeidet er gjennomført i samarbeid med professor David Gunnell fra School of Social and Community Medicine, Bristol University, som i en årrekke har forsket på selvmordsepidemiologi og -forebygging med utgangspunkt i data fra både Europa og Asia, og han er for tiden medlem av The National Suicide Prevention Advisory Group i England.

\section{Erlend Hem}

erlend.hem@medisin.uio.no

Tidsskriftet

\section{Litteratur}

1. Bjørngaard JH, Bjerkeset O, Vatten L et al. Maternal age at child birth, birth order and suicide at young age - a sibling comparison. Am J Epidemiol 2013; e-publisert 10.3.2013.
Ordforklaringer

Selvmord: Selvmord er blant de hyppigste årsakene til død i ung alder. Ifølge Nasjonalt folkehelseinstitutt døde 434 menn (17 per 100000 per år) og 164 kvinner (seks per 100000 per år) av selvmord i Norge i 2011 (1). Kunnskap om faktorer som kan bidra til forebygging av selvmord fra ung alder er derfor viktig.

\section{Litteratur}

1. Nasjonalt folkehelseinstitutt. Helsetilstanden i Norge: Selvmord og selvmordsfors $\varnothing \mathrm{k}$ www.fhi.no/eway/default.aspx?pid=233\&trg= MainLeft 6039\&MainArea 5661 $=6039: 0: 15,4576$. $1: 0: 0: 0: 0 \&$ MainLeft_6039=6041:70808:15,4576:1: 6043:1:0:0 (18.2.2013).

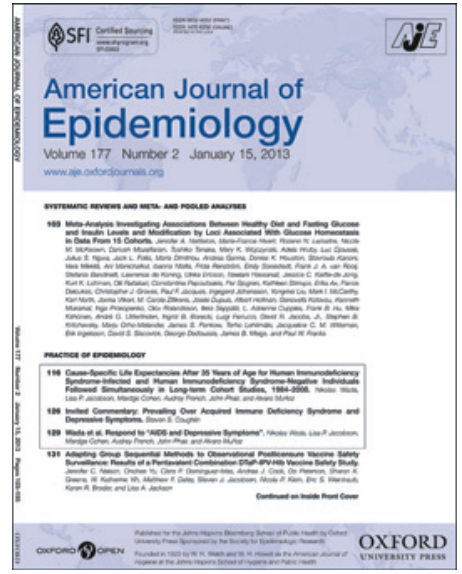

Artikkelen ble e-publisert 10.3. 2013 i det prestisjetunge tidsskriftet American Journal of Epidemiology (http://aje.oxfordjournals.org) 